\title{
The Role of the Supervisor of English Language and the Obstacles to His Performance in the Ministry of Education from Supervisors' Own Perspective in Light of Some Variables in Jordan
}

\author{
MS. Nejod Abdallah Iyadeh Al Massarwah \\ Jordan - Al-Karak
}

\begin{abstract}
The study aimed to identify the role of the educational supervisor of english language and the obstacles to his performance from the supervisors' own perspective in the light of some variables in Jordan. To reveal the status quo of supervisory practices, the study population was (57), a field study was conducted on (35) educational supervisors, representing (61.41\%) of the total community. The questionnaire was used as a main tool for data collection and it consisted of five axes: supervision principles, characteristics of educational supervision, interests and problems facing educational supervision and obstacles of development. The validity and reliability of the study was investigated as the overall reliability coefficient was (0.884). The results of the study showed that the lowest arithmetic means in study sample responses were in the axes of problems facing educational supervision and the obstacles to its development, while the highest arithmetic means were in favor of the axes of characteristics and principles of educational supervision. The results also showed that there were statistically significant differences at the level of $(\alpha=0.05)$ between the arithmetic means of the study sample responses in the axis of educational supervision principles, in favor of educational supervisors with academic qualifications in (higher than BA). The results of the study also showed that there were statistical differences in the axe of educational supervisors 'interests in favor of years of experience in supervision (more than 5 years). As far as the axes of educational supervision problems and obstacles to its development are concerned, the results of the study showed that there were statistically significant differences in favor of (supervision with experience 5 years or less). According to the study results, many recommendations and suggestions were introduced.
\end{abstract}

Keywords: Supervision, Educational Supervisor, Obstacles ,English Language.

DOI: $10.7176 / \mathrm{JEP} / 12-31-04$

Publication date: November $30^{\text {th }} 2021$

\section{INTRODUCTION:}

The educational systems are constantly keen to develop their system elements in order to preserve its sustainability and effectiveness, and educational supervision is one of its essential components related to the evaluation of performance, which has received great attention since its very beginning as educational inspection and until it has reached the concept of educational supervision with its characteristics, various tasks and roles, competence needed to encounter educational problems related to learning environment development related to learning environment development and increasing the effectiveness of the new teachers (Invoice Teachers) (especially those unqualified .

Educational supervision basic end is to bring about a better investment and utilization of the available resources at school that serve the process of implementing the curriculum and the plans emerging from the new developmental programs .From this point, the significance of educational supervision stems starting from its authority, tasks and expected roles, which, as a whole, endeavor to improve the educational process and learning. It is the authority that depends mainly on trust, persuasion and mutual dialogue. Generally speaking, educational supervision seeks to achieve the quality of education and improve that quality as it is one of the educational processes pertaining to the teaching and learning process, where it resorts to all methods and procedures required to identify the needs of the educational process and the requirements needed to improve its overall performance level in order to reach mastery, as it represents the link between the educational field and the responsible bodies, as it has to do with the technical side of the Ministry of Education and provides it with real information regarding the positive aspects of work and the prospects of development upon which decisions are taken (Ibrahim, 2009).

As for the competency of educational supervision and methods to develop, Dreij (2006) presented a model for the application of the competencies principle in the field of educational supervision, including multiple tasks performed by the educational supervisor, starting from positive communication with teachers, stimulating their motivation, encouraging career development and Providing more convenient conditions for the change required in teaching and learning process through the use of personal influence based on integrity, frankness and trust instead of the authority of official laws and regulations, and through task- related competencies the supervisor has acquired. His study also tackled a list of the main tasks and competencies represented by scientific and 
educational, research, development, planning, educational activation, creativities and innovation, organization, and follow-up competencies. Most of the studies had also been in consensus to confirm one of the important roles played by the educational supervisor, which was to develop students' follow-up and evaluation process through regular evaluation methods such as tests and semester examinations, in addition, importance of continuous evaluation methods that represented in continuous follow-up for students' performance.

\section{THEORETICAL FRAMEWORK AND PREVIOUS STUDIES.2}

The educational supervisor is a technical expert whose main duty is to assist teachers in professional growth and solve teaching problems facing them, in addition to providing technical services to improve teaching methods and put the educational process in the right direction. This requires knowledge of (the principles of Islamic education, learning theories, teaching methods, measurement and evaluation, management skills, communication and dealing with Education aids according to their majors).

\section{ELEMENTS OF THE EDUCATIONAL SUPERVISOR}

1. Vast experience: It comes through the practice of teaching, educational supervision, constant knowledge and organized reading. This involves the following:

a. A sufficient knowledge in the field of specialization.

b- Lesson planning skills.

2- Shura (consultation) and Cooperation: In terms of developing social skills among teachers and participating in decision-making.

3- Renewal: Discovering the most successful teaching methods and the ability to use technology positively.

4- Interest in growth : This comes through the interest in enhancing good attitudes, refining desirable skills, and promoting positive behavior.

5- Planning: Through the daily, weekly and semester plan to avoid improvisation and chaos, the plan must be free of stereotypes and repetition.

\section{THE DUTIES OF THE EDUCATIONAL SUPERVISOR}

First: General tasks (planning and administrative)

1. Preparing a comprehensive supervision plan in the form of stages.

2. Being acquainted with the instructions and regulations related to educational work.

Second: - Special (technical) tasks:

\section{1- Student related :}

a- A care of the integrated growth of the student (religiously, scientifically, practically and socially) without being limited to cognitive growth only.

b - Taking into account individual differences.

2- Teacher evaluation - related:

a - Regular and integrated Preparation of lessons.

b- Measuring students 'response.

3- Curricula, and textbooks -related:

First: Tasks related to the curriculum:

A-Introducing the curriculum with its broad sense, which includes educational experiences inside and outside school to help in comprehensive growth.

b- Development of positive trends and effective ways of thinking.

Second: Tasks related to academic courses and material:

a - Study the regulations and circulars related to school curricula.

$\mathrm{b}$ - Awareness of the objectives of the courses in the various stages in terms of follow- up, deletion and addition.

Third: Tasks related to textbooks:

a - Ensure that school books are delivered according to the authorized editions.

b. Discussing teachers with school books and continuing to evaluate them.

4- School facilities and equipment - related

A- being informed on the list of educational aids issued by the competent authorities in the Ministry of Education.

$\mathrm{b}$ - identifying the educational means available in schools and pinpointing the shortage.

5- Training- related :

a - Proposing training programs necessary for teachers, analyzing their professional situations, and determining the skills to be developed through training.

b- Participation in selecting teachers for training programs.

6- School activities - related: 
a - Directing teachers towards the importance and necessity of school activity.

b- Investigating the types of activities related to the subjects in all classes.

\section{OBSTACLES TO EDUCATIONAL SUPERVISION \\ Administrative obstacles:}

1. The excessive administrative burdens educational supervisors the teachers experience. The educational process is a complex, interrelated and multifaceted process that requires time, effort and devotion. Nevertheless, the educational supervisor is asked to visit a number of teachers that exceeds the prescribed quorum up to twice . despite this, administrative duties are assigned to him that restricts his field activity and perhaps modifies his plan. This affects his performance and activity in Preparing brochures, seminars, training programs and actual follow-up of his essential tasks. The teacher also complains about the over crowdedness and accumulation of the tasks, which does not provide him with time to review supervisor's recommendations and implement and benefit from them.

2- Lack of training courses for educational supervisors and teachers: In-service training is necessary for the educational supervisor and the teacher due to the changing situations each of them face as they work for the human being. Without training, information diminishes and disappears. Needless to say, teacher's or supervisor's adherence to one method in teaching may instill one character among students.

3- Lack of ability in practice educational supervision among school principals: The school administration is an executive and supervisory educational leadership, and it assumes responsibilities that make it need distinct educational competencies. However, some of these administrations complain of weakness either in personality or in the ability to supervise, follow-up and evaluation, or either in the scientific and educational ability. The administration may be authoritative or Laissez-faire. and thus this has negative impact on all elements of the educational process

\section{ECONOMIC OBSTACLES:}

1- The lack of educational tools necessary for the teaching and learning processes.

2. Lack of financial incentives for supervisors and teachers.

3- Lack of libraries (or lack of books) in schools, and this has resulted in less interest in reading and renovation among students or teachers. indeed, there are teachers who do not pay any attention to educational publications even though they are the best and most informed supervision methods.

\section{TECHNICAL OBSTACLES:}

1-Some teachers comply with the educational supervisor's guidance .

2- Incompetence of the teacher or the supervisor. There is weakness in terms of information or personality or reaction to emergent situations or experience and such thing exists also among teachers. It has been said that some teachers have nothing to do with competence and that they are so- called teachers .

\section{SOCIAL OBSTACLES:}

The inconvenient school environment, for example, rented premises that do not provide security and safety tools, lack of the necessary laboratories, large spaces for sports activities, theaters for cultural and drama activities.

\section{Personal obstacles:}

1- Some supervisors and principals are not able to follow appropriate leadership styles

2- Weakness of the relationship between supervisors, principals and teachers .

3- The emergence of some personal problems and their impact on work sometimes.

\subsection{PREVIOUS STUDIES:}

(Abu Hussein, 2012) The research aimed to identify the obstacles to the practice of electronic supervision from the point of view of the educational supervisors in the city of Abha. The research sample consisted of (69) educational supervisors on whom a questionnaire was applied to collect data. The results showed that the technical obstacles are the most obstacles to electronic supervision from the viewpoint of the educational supervisors in the city of Abha, followed by the material obstacles, then the organizational obstacles, and finally the human obstacles. The results also indicated that there are no statistically significant differences between the averages of the study sample about the obstacles to practicing electronic supervision due to the variables of specialization and qualification, while there are differences due to the years of experience variable.

(Al Qahtani ,2020)The success of the educational process depends on the good selection of the educational supervisor, who is the pillar of the Fustat in relation to the educational process and the link between its various components, hence this research, which is entitled "Developing the criteria for selecting the educational supervisor in the Kingdom of Saudi Arabia in light of the vision of 2030 AD. This research contains an introduction, a preamble, six axes, the most important results and recommendations, and a topic index. The 
introduction included: the importance of research, research objectives, research methodology, research procedures, and research plan. The preface included: definition of the term criteria and its linguistic implications, and definition of the Kingdom's vision for 2030. As for the research axes, they are: the definition of the educational supervisor - the importance of the educational supervisor - the tasks of the educational supervisor the stages of development of the criteria for selecting the educational supervisor in Saudi Arabia - Vision 2030 and the centrality of the role of education and educational supervision - the pillars of developing the criteria for choosing the educational supervisor to align with the 2030 vision. The researcher concluded that the existence of five pillars to develop the educational supervisor selection according to the vision of $2030 \mathrm{AD}$, some of which are related to the supervisor, his personality and his knowledge, and some of them relate to the same selection criteria. The researcher recommended working to keep abreast of developments in the field of educational supervision by constantly reviewing the criteria for selecting educational supervisors, working to qualify educational supervisors in the Ministry of Education in the Kingdom of Saudi Arabia, in line with modern educational development.

\section{STATEMENT OF THE PROBLEM AND QUESTIONS:}

The problem of the study is determined by revealing the status of the practices of educational supervision in Jordan after the establishment of the Department of Educational Supervision in the general directorates of education, starting from the supervision principles, the reliable characteristics, as well as the interests and concerns of educational supervision. The following questions are determined by the study:

1 -What is the status of practices in educational supervision in jordan from the educational supervisors' perspective?

2- Does the status of educational supervision practices differ from the perspective of the study sample according to the gender, the type of supervision, the level of education, the number of experience years in teaching, the number of experience years in supervision, and the extent of interest in research in educational supervision.

\subsection{METHODOLOGY:}

To achieve the study objectives, the current study was based on a descriptive approach to describe the theoretical foundations of educational supervision related to its principles, roles, tasks and their analysis. Supervision practices and their relationship to some variables were analyzed qualitatively and quantitatively in the field.

\subsection{STUDY SIGNIFICANCE:}

The importance of the current study is determined in the following :

1- It defines the educational principles followed by the educational supervisor during supervision process

2- It reveals the educational supervisor's characteristics during supervision process

3- It clarifies the most prominent roles the educational supervisor plays during the performance of his duties

4- It reveals the factors that hinder the educational supervisor performance.

\subsection{THE LIMITS OF THE STUDY:}

The study was confined to a sample of educational supervisors in Jordan for the academic year 2020/2021.

\subsection{METHODOLOGY AND PROCEDURES:}

The study population consisted of (57) male and female supervisors while the study sample was (35) individuals, representing (61.41\%), and they were distributed according to the study variables as shown in Table (1):

\begin{tabular}{|c|c|c|c|}
\hline Variables & Level & Number & Percentage \\
\hline \multirow[t]{2}{*}{ Gender } & Female & 20 & 57 \\
\hline & Male & 15 & 43 \\
\hline \multirow[t]{2}{*}{ Type of supervision } & general supervisor & 17 & 48.57 \\
\hline & specialized supervisor & 18 & 51.42 \\
\hline \multirow[t]{2}{*}{ Academic degree } & MA & 24 & 68.57 \\
\hline & PHD & 11 & 31.42 \\
\hline \multirow{3}{*}{$\begin{array}{r}\text { Years of experience in } \\
\text { teaching }\end{array}$} & Less than 5 years & 11 & 31.42 \\
\hline & From 5-9 years & 16 & 45.71 \\
\hline & more than 5 years & 8 & 22.85 \\
\hline \multirow{2}{*}{$\begin{array}{r}\text { Years of experience in } \\
\text { supervision }\end{array}$} & Less than 5 years & 19 & 54.28 \\
\hline & more than 5 years & 17 & 48.57 \\
\hline \multirow{2}{*}{$\begin{array}{r}\text { Conducting research in } \\
\text { supervision field }\end{array}$} & Yes & 23 & 65.71 \\
\hline & No & 12 & 34.28 \\
\hline
\end{tabular}


Table (1) shows that (57\%) of the study sample are females, compared to (43\%) of males, and $(48.1 \%)$ of the study sample are first supervisors, while (48.57\%) specialized supervisors. As for the type of qualification, $(68.57 \%)$ of the sample has bachelor degree or less. As for the number of experience years in supervision variable, $(54.28 \%)$ of the sample has (5 years or less) experience.

\subsection{STUDY INSTRUMENT:}

In order to reveal the role of educational supervision from the educational supervisors' perspective, a questionnaire was prepared as a main tool for data collection, by analyzing previous studies that dealt with educational supervision, its roles, tasks and characteristics, in addition to theoretical literature. (Appendix 1) consists of two parts:

The first part: included an introduction to the title of the study and its importance, and general required data to be collected about the respondents and their psychometric characteristics in terms of gender, educational level, number of experience years in the field of teaching, and in the field of supervision, and conducting research in the field of supervision.

The Part Two: consists of (90) paragraphs related to educational supervision, they were classified into five axes:

1-The first axis: the principles of educational supervision, (16) paragraphs.

2-The second axis: the characteristics of educational supervision, (20), paragraphs.

3- The third axis: the supervision interests of the educational supervisor, (23) paragraphs.

4-The fourth axis: The problems facing the educational supervisor, (14) paragraphs.

5- Fifth Axis: Obstacles to the development of educational supervision, (17) paragraphs

\subsection{TOOL VALIDITY AND RELIABILITY:}

The validity of the tool's content was verified by a committee of arbitrators who are members of the teaching staff in the College of Education in the majors of educational supervision and educational administration. They were asked to express their opinions about data in the questionnaire which reflected the role of educational supervision from the educational supervisors' point of view regarding the previous axes referred to and in light of the observations and suggestions being taken into consideration.

In order to verify the reliability of the tool, the Cronbach coefficient of Alpha for internal consistency was calculated, where the field of supervision interests accounted for $(0.721)$, while the axis of problems faced by the educational supervisor was $(0.774)$. The axis of obstacles to the educational supervision was $(0.739)$. The axis of principles of educational supervision accounted for $(0.765)$, and the axis of the characteristics of educational supervision $(0.864)$, as for the total, it reached $(0.884)$ as shown in table (2).

Cronbach for the total study axes and alpha reliability coefficient :Table (2)

\begin{tabular}{|c|l|c|c|}
\hline$\#$ & Study axes & Number of items & Alpha - Cronbach \\
\hline 1 & educational supervision interests & 23 & 0.721 \\
\hline 2 & problems facing the educational supervisor & 14 & 0.774 \\
\hline 3 & Obstacles to educational supervision development & 17 & 0.739 \\
\hline 4 & Principles of educational supervision & 16 & 0.765 \\
\hline 5 & Characteristics of educational supervision & 20 & 0.864 \\
\hline $\mathbf{6}$ & Total & 90 & 0.884 \\
\hline
\end{tabular}

\subsection{STUDY VARIABLES:}

1-Gender variable, and it has two categories (male and female).

2-Supervision type variable, and it has two categories (first Supervisor, material supervisor).

3-A variable of educational level and has two levels (Master and below, $\mathrm{PhD}$ ) .

4- A variable of number of experience years in teaching, with three levels (less than 5 years, from 5 years to 9 years, and more than 9 years).

5- The number of experience years in supervision variable and has two levels ( 5 years or less, more than 5 years). 6- A variable of the level of research achievement in the field of educational supervision, and it has two categories (yes, no).

\subsection{SECOND, THE DEPENDENT VARIABLE:}

The scores of the study sample on the questionnaire items, which express the role of educational supervision in its five axes.

\subsection{STUDY RESULTS AND DISCUSSION:}

Since this study used a descriptive approach that relies on data and statistics that express the role of educational supervision and its assigned tasks practices, the results of the study will be in accordance to its questions. 
The standard of reference (Norm-Reference) was built by using the average of the arithmetic means for the overall responses of the study sample as a cut-score to account for the results (Al-Nabhan, 2004) (where the values above the average of the arithmetic means with one standard deviation are agreed to be "high" and those below one standard deviation are agreed to be "low". Those between the two levels are agreed to be "mid" as follows

1 - The arithmetic mean (from 0.81 and above) indicates a "high" degree of practice

2-The arithmetic mean (0.80-0.58) indicates a "medium" degree of practice.

3 -The arithmetic mean ( 0.57 and below) indicates a low level of practice.

Since this study used a descriptive approach that relies on data and statistics that express the role of educational supervision the results of the study will be in accordance to its questions as follows:

First: Introducing the results of the first question, which aims to reveal the role of educational supervision from supervisors' own perspective, in terms of the characteristics of supervision work, its principles, and supervision interests. In addition, the problems that the educational supervisor faces as well as obstacles to the development of the educational supervision. The arithmetic means and standard deviations of the responses of the study sample members were calculated on all its items and axes, as shown in table (3) .

Table (3) :The arithmetic means and standard deviations to the responses of the study sample individuals on all study axes, arranged descendingly, and the tool as a whole.

\begin{tabular}{|c|r|c|c|c|}
\hline Rank & Axes & arithmetic mean & standard deviation & Level \\
\hline 1 & Characteristics of educational supervision & 0.87 & 0.17 & high \\
\hline 2 & Principles of educational supervision & 0.87 & 0.15 & High \\
\hline 3 & educational supervision interests & 0.72 & 0.14 & mid \\
\hline 4 & problems facing the educational supervisor & 0.51 & 0.25 & Low \\
\hline 5 & Obstacles to educational supervision development & 0.50 & 0.21 & Low \\
\hline & Total & 0.69 & 0.12 & mid \\
\hline
\end{tabular}

shows that the highest arithmetic mean is in favor of the axes of characteristics of educational supervision, and the principles of educational supervision (0.87) for each. Consequently, the confirmation is clear through the response of the educational supervisors.

on the importance of the characteristics and principles of educational supervision, which are among the backbone of their work, especially during their performance of the roles assigned to them. The results of the study also revealed that the arithmetic mean of supervision interests was scored as "medium" (0.72). As for the problems facing the educational supervisor and the obstacles to developing educational supervision, their arithmetic means were "low" with an average of $(0.51)$ and $(0.50)$ respectively. With regard to the most prominent roles the educational supervisor plays and were revealed by the results of the study, their frequency and percentage were calculated as follows:

1 - Discussion with teachers through work sessions.

Assistance in the process of units and lessons planning.

3- Assessment and building tests.

Direct assistance to workers in the educational field.

Tackling teachers 'personal problems.

Organizing continuous meetings with the school principal and teachers.

Visiting teachers and administrators individually.

8 - instant issuance of decisions and proposals.

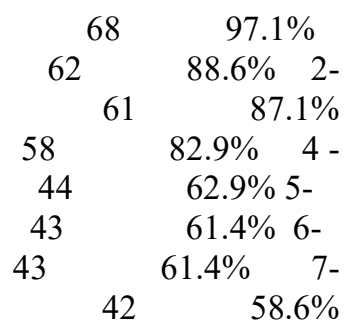

It is noticed that the most important roles played by the educational supervisor are as follows: first , discussion teachers through counseling sessions at a rate of $(97.1 \%)$, then, assistance in the process of planning units and lessons (88\%). The supervisor's role in instant issuance of decisions and proposals is regarded the lowest and at a rate of (58.6\%). As for the results of the study sample individuals' responses on each axis of the study, the arithmetic mean and standard deviations were extracted for all the items contained in each axis as shown in Appendix (2) as Table (a) in the appendix presented, the arithmetic means and standard deviations of (16) educational principles of educational supervision had been mentioned - the arithmetic means of (13) of them were "high". The highest scores were for the principle of interest in individual differences among students $(0,97)$ and then the principle of interest in aids and materials, modern educational technologies $(0,97)$ and interest in innovation, during the presentation of the lesson (0.96). As for the principles with "medium" arithmetic means, they were only two principles: improving the human relations of school staff $(0,71)$ and the principle of application the mini-teaching method and peer observation $(0.61)$ while the lowest mean $(0.57)$ was for a sole principle " work and assistance in developing future leaderships of principals and supervisors.

Second: This axis includes the answer to the second question, which aims to explore the statistically significant differences $(\alpha=0.05)$ between the responses of the educational supervisors, which reflects their supervisory practices, the problems they encounter, and the obstacles to the development of educational supervision. These are attributed to difference in gender, type of supervision, the level of education, the number 
of experience years in teaching, the number of experience years in supervision, and the level of research achievement in educational supervision

The arithmetic means of the responses of the study sample individuals were extracted in relation to all variables, and the (t) test and the (One Way ANOVA) test were also conducted to reveal the statistically significant differences attributed to the study variables. $(t)$ test was conducted to the statistically significant differences ascribed to the variables of gender, type of supervision, the academic degree of the educational supervisor, and the number of experience years in supervision, as shown in table (4).

Table (4): Results of the t-test analysis for the responses of the study sample according to the variables of type, type of supervision, the educational supervisor's academic degree and the number of years of experience in supervision within the study axes.

\begin{tabular}{|c|c|c|c|c|c|c|c|}
\hline Variables & Study axes & $\begin{array}{l}\text { level of } \\
\text { variables }\end{array}$ & number & $\begin{array}{l}\text { Arithmetic } \\
\text { mean }\end{array}$ & $\begin{array}{l}\text { Standard } \\
\text { deviation }\end{array}$ & $\begin{array}{c}\text { (t) } \\
\text { value }\end{array}$ & $\begin{array}{l}\text { Level of } \\
\text { significance }\end{array}$ \\
\hline \multirow{10}{*}{ Gender } & \multirow{2}{*}{$\begin{array}{l}\text { Supervision } \\
\text { characteristics }\end{array}$} & male & 15 & 0.861 & 0.188 & \multirow[t]{2}{*}{0.497} & \multirow[t]{2}{*}{0.634} \\
\hline & & female & 20 & 0.880 & 0.131 & & \\
\hline & \multirow{2}{*}{$\begin{array}{l}\text { Supervision } \\
\text { Principles }\end{array}$} & male & 15 & 0.685 & 0.139 & \multirow[t]{2}{*}{0.161} & \multirow[t]{2}{*}{0.873} \\
\hline & & female & 20 & 0.871 & 0.168 & & \\
\hline & \multirow{2}{*}{$\begin{array}{l}\text { Supervisor's } \\
\text { interest }\end{array}$} & male & 15 & 0.704 & 0.144 & \multirow[t]{2}{*}{0.879} & \multirow{2}{*}{0.383} \\
\hline & & female & 20 & 0.735 & 0.142 & & \\
\hline & \multirow{2}{*}{$\begin{array}{l}\text { Problems he/she } \\
\text { faces }\end{array}$} & male & 15 & 0.527 & 0.231 & \multirow[t]{2}{*}{0.623} & \multirow[t]{2}{*}{0.535} \\
\hline & & female & 20 & 0.489 & 0.268 & & \\
\hline & \multirow{2}{*}{$\begin{array}{l}\text { Obstacles for } \\
\text { supervision } \\
\text { development }\end{array}$} & male & 15 & 0.509 & 0.202 & \multirow[t]{2}{*}{0.630} & \multirow[t]{2}{*}{0.531} \\
\hline & & female & 20 & 0.477 & 0.232 & & \\
\hline \multirow{10}{*}{ Supervision } & \multirow{2}{*}{$\begin{array}{l}\text { Supervision } \\
\text { characteristics }\end{array}$} & specialized & 17 & 0.841 & 0.210 & \multirow[t]{2}{*}{1.498} & \multirow[t]{2}{*}{0.139} \\
\hline & & general & 18 & 0.900 & 0.093 & & \\
\hline & \multirow{2}{*}{$\begin{array}{l}\text { Supervision } \\
\text { Principles }\end{array}$} & specialized & 17 & 0.850 & 0.178 & \multirow[t]{2}{*}{1.019} & \multirow[t]{2}{*}{0.312} \\
\hline & & general & 18 & 0.886 & 0.112 & & \\
\hline & \multirow{2}{*}{$\begin{array}{l}\text { Supervisor's } \\
\text { interest }\end{array}$} & specialized & 17 & 0.699 & 0.136 & \multirow[t]{2}{*}{1.074} & \multirow[t]{2}{*}{0.287} \\
\hline & & general & 18 & 0.736 & 0.151 & & \\
\hline & \multirow{2}{*}{$\begin{array}{l}\text { Problems he/she } \\
\text { faces }\end{array}$} & specialized & 17 & 0.552 & 0.241 & \multirow[t]{2}{*}{1.435} & 0.151 \\
\hline & & general & 18 & 0.468 & 0.245 & & \\
\hline & Obstacles for & specialized & 17 & 0.502 & 0.223 & 0.237 & 0.813 \\
\hline & $\begin{array}{l}\text { supervision } \\
\text { development }\end{array}$ & general & 18 & 0.490 & 0.205 & & \\
\hline & $\begin{array}{l}\text { Supervision } \\
\text { characteristics }\end{array}$ & $\begin{array}{l}\text { Master and } \\
\text { below }\end{array}$ & 24 & 0.846 & 0.193 & 1.605 & 0.113 \\
\hline & & PHD & 11 & 0.913 & 0.088 & & \\
\hline & Supervision & $\begin{array}{l}\text { Master and } \\
\text { below }\end{array}$ & 24 & 0.840 & 0.168 & 2.156 & 0.035 \\
\hline Academic & Principles & PHD & 11 & 0.919 & 0.091 & & \\
\hline $\begin{array}{l}\text { Qualifica } \\
\text { Tions }\end{array}$ & $\begin{array}{l}\text { Supervisor's } \\
\text { interest }\end{array}$ & $\begin{array}{l}\text { Master and } \\
\text { below }\end{array}$ & 24 & 0.710 & 0.154 & 0.525 & 0.602 \\
\hline & & PHD & 11 & 0.729 & 0.123 & & \\
\hline & $\begin{array}{l}\text { Problems he/she } \\
\text { faces }\end{array}$ & $\begin{array}{l}\text { Master and } \\
\text { below }\end{array}$ & 24 & 0.505 & 0.235 & 0.356 & 0.723 \\
\hline & & PHD & 11 & 0.527 & 0.268 & & \\
\hline & $\begin{array}{l}\text { Obstacles for } \\
\text { supervision }\end{array}$ & $\begin{array}{l}\text { Master and } \\
\text { below }\end{array}$ & 24 & 0.489 & 0.192 & 0.440 & 0.661 \\
\hline & development & PHD & 11 & 0.512 & 0.252 & & \\
\hline & $\begin{array}{l}\text { Supervision } \\
\text { characteristics }\end{array}$ & $\begin{array}{l}\text { below } 5 \\
\text { years }\end{array}$ & 23 & 0.864 & 0.174 & 0.337 & 0.737 \\
\hline & & $\begin{array}{l}\text { more than } \\
5 \text { years }\end{array}$ & 12 & 0.878 & 0.156 & & \\
\hline $\begin{array}{l}\text { Experience } \\
\text { in }\end{array}$ & Supervision & $\begin{array}{l}\text { below } 5 \\
\text { years }\end{array}$ & 23 & 0.867 & 0.140 & 0.004 & 0.996 \\
\hline supervision & Principles & $\begin{array}{l}\text { more than } \\
5 \text { years }\end{array}$ & 12 & 0.867 & 0.173 & & \\
\hline
\end{tabular}




\begin{tabular}{|c|c|c|c|c|c|c|}
\hline \multirow[t]{2}{*}{$\begin{array}{l}\text { Supervisor's } \\
\text { interest }\end{array}$} & $\begin{array}{l}\text { below } 5 \\
\text { years }\end{array}$ & 23 & 0.692 & 0.136 & \multirow[t]{2}{*}{2.158} & \multirow[t]{2}{*}{0.35} \\
\hline & $\begin{array}{l}\text { more than } \\
5 \text { years }\end{array}$ & 12 & 0.768 & 0.146 & & \\
\hline \multirow[t]{2}{*}{$\begin{array}{l}\text { Problems he/she } \\
\text { faces }\end{array}$} & $\begin{array}{l}\text { below } 5 \\
\text { years }\end{array}$ & 23 & 0.565 & 0.241 & \multirow[t]{2}{*}{2.709} & \multirow[t]{2}{*}{0.009} \\
\hline & $\begin{array}{l}\text { more than } \\
5 \text { years }\end{array}$ & 12 & 0.404 & 0.219 & & \\
\hline \multirow{2}{*}{$\begin{array}{l}\text { Obstacles for } \\
\text { supervision } \\
\text { development }\end{array}$} & $\begin{array}{l}\text { below } 5 \\
\text { years }\end{array}$ & 23 & 0.536 & 0.214 & \multirow[t]{2}{*}{2.255} & \multirow{2}{*}{0.27} \\
\hline & $\begin{array}{l}\text { more than } \\
5 \text { years }\end{array}$ & 12 & 0.417 & 0.193 & & \\
\hline
\end{tabular}

\section{A significance at the level $(\alpha=0,05)$.}

Table (4): showed the results of the $(\mathrm{t})$ test that revealed the statistically significant differences between the arithmetic means of the responses of the members of the study sample, as there were no statistically significant differences due to the gender variables and the type of supervision on all study axes. With regard to the academic qualification variable, the study results revealed that there were statistically significant differences among the responses of the individuals of the study sample in the axe of the principles of educational supervision in favor of academic qualification higher than a bachelors degree with an arithmetic mean (0.919). For the variable of the number of experience years in educational supervision, there were statistically significant differences between the responses of the study sample individuals in the axe of the educational supervisor's interests and in favor of the column (more than 5 years). In the axe of educational supervision problems and obstacles to its development, the highest arithmetic means were scored in favor of the column (5 years or more), with arithmetic means $(0.565)$ and (0.536), respectively.

As for the variable number of experience years in teaching and research in the field of educational supervision is concerned, the arithmetic means and standard deviations were extracted for the responses of the individuals of the study sample on all its axes, as shown in table (5).

table (5): The arithmetic means and standard deviations to the responses of the study sample individuals on all its axes according to the variables of the years of experience in teaching and research work in the field of educational supervision.

\begin{tabular}{|c|c|c|c|c|c|c|c|c|}
\hline \multirow{3}{*}{ Study axes } & \multicolumn{4}{|c|}{ experience in teaching } & \multicolumn{4}{|c|}{ experience in research } \\
\hline & \multicolumn{2}{|c|}{ Less than 5 years } & \multicolumn{2}{|c|}{ more than 5 years } & \multicolumn{2}{|c|}{ Yes } & \multicolumn{2}{|c|}{ No } \\
\hline & $\begin{array}{l}\text { arithmeti } \\
\text { c mean }\end{array}$ & $\begin{array}{c}\text { Standard } \\
\text { deviatio } \\
n\end{array}$ & $\begin{array}{c}\text { arithmeti } \\
\text { c mean }\end{array}$ & $\begin{array}{c}\text { Standard } \\
\text { deviatio } \\
n\end{array}$ & $\begin{array}{c}\text { arithmeti } \\
\text { c mean }\end{array}$ & $\begin{array}{c}\text { Standard } \\
\text { deviatio } \\
n\end{array}$ & $\begin{array}{c}\text { arithmeti } \\
\text { c mean }\end{array}$ & $\begin{array}{c}\text { Standard } \\
\text { deviatio } \\
n\end{array}$ \\
\hline Interests & 0.706 & 0.155 & 0.728 & 0.151 & 0.717 & 0.140 & 0.695 & 0.139 \\
\hline $\begin{array}{c}\text { Characteristic } \\
\text { s }\end{array}$ & 0.863 & 0.206 & 0.862 & 0.149 & 0.864 & 0.134 & 0.869 & 0.258 \\
\hline Principles & 0.856 & 0.140 & 0.864 & 0.187 & 0.886 & 0.155 & 0.859 & 0.166 \\
\hline Obstacles & 0.419 & 0.225 & 0.549 & 0.225 & 0.489 & 0.225 & 0.537 & 0.193 \\
\hline Problems & 0.491 & 0.264 & 0.496 & 0.248 & 0.500 & 0.264 & 0.598 & 0.223 \\
\hline
\end{tabular}

Although there are apparent differences between the arithmetic means of the study sample responses the according to the variables of the number of experience years in teaching and conducting research in the field of educational supervision, it is necessary to conduct a statistical investigation, a one variance analysis for the responses of the individuals of the study sample was conducted, as shown in table (6). 
Table (6): The results of the one variance analysis to the responses of the study sample individuals according to the variables of the number of years.

\begin{tabular}{|c|c|c|c|c|c|c|c|}
\hline Variables & Axes & Variance & Sum & d. $f$ & Mean & F value & significance \\
\hline \multirow{10}{*}{ conducting research } & \multirow[t]{2}{*}{ Problems } & between groups & 0.180 & 2 & 0.090 & \multirow[t]{2}{*}{1.524} & \multirow[t]{2}{*}{0.225} \\
\hline & & within groups & -- & 32 & 0.059 & & \\
\hline & \multirow[t]{2}{*}{ Interests } & between groups & 0.016 & 2 & 0.008 & \multirow[t]{2}{*}{0.374} & \multirow[t]{2}{*}{0.684} \\
\hline & & within groups & 1.400 & 32 & 0.021 & & \\
\hline & \multirow[t]{2}{*}{ Principles } & between groups & 0,011 & 2 & 0.001 & \multirow[t]{2}{*}{0.030} & \multirow[t]{2}{*}{0.971} \\
\hline & & within groups & 1.561 & 32 & 0.23 & & \\
\hline & \multirow[t]{2}{*}{ Characteristic } & between groups & 0.004 & 2 & 0.001 & \multirow[t]{2}{*}{0.061} & \multirow[t]{2}{*}{0.941} \\
\hline & & within groups & 1.927 & 32 & 0.029 & & \\
\hline & \multirow[t]{2}{*}{ Obstacles } & between groups & 0.037 & 2 & 0.019 & \multirow[t]{2}{*}{0.402} & \multirow[t]{2}{*}{0.670} \\
\hline & & within groups & 3.095 & 32 & 0.046 & & \\
\hline \multirow{10}{*}{ Experience in teaching } & \multirow[t]{2}{*}{ Problems } & between groups & 0.046 & 2 & 0.23 & \multirow[t]{2}{*}{0.377} & \multirow[t]{2}{*}{0.687} \\
\hline & & within groups & 4.096 & 32 & 0.061 & & \\
\hline & \multirow[t]{2}{*}{ Interests } & between groups & 0.006 & 2 & 0.003 & \multirow[t]{2}{*}{0131} & \multirow[t]{2}{*}{0.878} \\
\hline & & within groups & 1.410 & 32 & 0.021 & & \\
\hline & \multirow[t]{2}{*}{ Principles } & between groups & 0.007 & 2 & 0.004 & \multirow[t]{2}{*}{2.155} & \multirow[t]{2}{*}{0.857} \\
\hline & & within groups & 1.555 & 32 & 0.023 & & \\
\hline & \multirow[t]{2}{*}{ Characteristic } & between groups & 0.003 & 2 & 0.001 & \multirow[t]{2}{*}{0.047} & \multirow[t]{2}{*}{0.954} \\
\hline & & within groups & 1.928 & 32 & 0.029 & & \\
\hline & \multirow[t]{2}{*}{ Obstacles } & between groups & 0.215 & 2 & 0.107 & \multirow[t]{2}{*}{2.468} & \multirow[t]{2}{*}{0.092} \\
\hline & & within groups & 2.918 & 32 & 0.044 & & \\
\hline
\end{tabular}

Experience in teaching and research conducting in educational supervision:

The results of the (One Way ANOVA) showed that there were no statistically significant differences ascribed to the variables of the number of experience years in teaching and conducting research in the field of educational supervision in all relevant axes. As it appeared from the results of the second question in table (4) which contained the analysis results of the $(t)$ test. That the column of educational supervisors a scientific qualification (higher than a bachelor's) emphasized the importance of supervisory principles in the process of educational supervision compared to the column of supervisors who had a qualification ( a bachelor's degree or less) . They were more caring about individual differences. And they paid more attention to the importance of implementation of modern educational aids, materials and technologies in the education process by teachers. They also encouraged innovation and creativity in lesson design and presentation. It can be hence said that the scientific qualification has an influence on supervisors' performance of their roles as the higher the academic qualifications they have, the higher the arithmetic mean of their scientific performance.

This result was consistent with Al-Momani study (2003), in that the high qualification of the educational supervisor makes him more familiar with the educational principles of educational supervision, especially those related to administrative skills and the principle of continuous learning, the enhancement of professional selfdevelopment, the principle of democracy, and joint cooperation in the fulfillment of tasks, in addition to linking school subjects to the local environment. As for the characteristics of educational supervision, there were no statistically significant differences $(\alpha=0.05)$ due to academic qualification, as all educational supervisors have common interests regarding the nature of the educational process and have sufficient knowledge of the information related to their field. They are keen for providing constructive and educational guidance to teachers without negative criticism. Their attention also revolves around the pursuit of initiative, creativity, development, time management and good organization.

As for the variable number of experience years in educational supervision; the results of the study revealed that the arithmetic means of the educational supervisors' responses (more than 5 years) were higher than those in the column (5 years and less). Therefore, years of supervisor's experience in educational supervision had an impact on the development of supervision interests related to observing the teacher's method during the lesson , guiding to use educational methods, and having interest in stimulating learners during the lesson. The study results also showed that educational supervisors from a column ( 5 years or less) face more supervisory problems such as the inability in providing equipment, tools and teaching courses, supervising a large number of schools , experiencing shortage of time and classroom over crowdedness. than their counterparts of supervisors from a column (5 years or more).

\section{4 .1 RECOMMENDATIONS AND SUGGESTIONS:}

1 - in order to develop supervision and make it more effective, it is necessary to create a database of information 
related to teachers' majors and supervision needs and thus achieve the contemporary approach in educational supervision based on knowledge (Knowledge-Based Supervision, or Information-Based Supervision).

2-Adopting decentralization in educational supervision by adopting the school principal's approach as a resident supervisor in charge of the process of coordination and follow-up with the educational supervisors inside or outside the school, and granting him tasks and authority to assume an effective supervisory role in the school.

3- Developing educational supervision methods, and adopting modern methods and models to assist teachers in self-directed and professional development.

4- Enriching the experiences of educational supervisors, providing them with skills in relation to planning for administrative and financial affairs, and setting up plans to develop educational supervision at the level of school and directorate.

5- Enhancing human relations among all school employees by establishing general educational principles and foundations that depend on continuous communication and mutual respect, and providing adequate opportunities to express their opinions and observations for the sake of harmony within the school environment

6- Raising the level of educational supervisors' performance by developing their supervisory leadership capabilities to assume responsibility of renewal self- reliance in pursuance of development in order to achieve the school's vision and its educational mission.

7- Establishing a procedural mechanism to discover future leaders from educational supervisors, and developing training programs before supervisory selection.

8- Diversification of the activities of training programs for the educational supervisors to match the renewed requirements in the field of educational supervision and renewal at school curricula and school in particular.

9- Conducting scientific work research by supervisors to solve the problems they face during their work, and adopting their results in developing the level of career development of teachers and themselves.

10- Diversification the supervision methods according to the situations that educational supervisors deals with while carrying out their work.

\section{REFERENCES}

- Ibrahim, Adnan Badri (2002) Educational Supervision, Styles and Methods, Irbid Jordan: Hamada Foundation for undergraduate and postgraduate Studies, Publishing and Distribution.

- Al-Dureij, Muhammad (2006): Competencies of the Educational Supervisor and Methods for Their Development, Tawasul Magazine, Omani National Commission for Education, Culture and Science, (4) June 2006.

- Al-Nabhan, Mousa (2004) Fundamentals of measurement in the behavioral sciences, Ram Allah: Dar AlShoroq for publication and distribution.

- Abu Hussein, Fatima (2021). Obstacles to electronic supervision from female supervisors' perspective in the urban city of Abha. Journal of Educational Studies and Research, vol. 1, edition. 1. January 2021.

- Al-Qahtani, Abeer (2020). Criteria Development to select the educational supervisor in the Kingdom of Saudi Arabia in light of Vision 2030. Arab Journal of Educational and Psychological Sciences. vol. edition, 13, 2020

- Attari, Arif Tawfiq and Aisan, Salha Abd Nari Man (2005). Educational Supervision, its theoretical approaches and practical applications, Kuwait: Al Falah Library for Publishing and Distribution.

- Al-Omari, Hassan Ahmad (2000) The extent of educational supervisors 'practice of the educational principles contained in the Education Law No. (3) of 1994, an unpublished master's thesis, Jordan Yarmouk University.

- Al-Taani, Hassan Ahmad (2005). Educational Supervision, its concepts, aims, foundations, and methods, revised by: Ahmad Battah, Amman, Jordan: Dar Al-Shoroq for Publishing and Distribution.

- Al-Dhafiri, Saeed (2009): The first teacher's perceptions and beliefs in the Sultanate of Oman on his role in school reform, School Reform Conference, United Arab Emirates University, United Arab Emirates, 17 $19 / 4$ / 2007.

- Fever, Isabel and Dunlap, Jane (1993). Educational Supervision on Teachers, translated by: Muhammad Eid Dirani, Revised by: Omar Al-Sheikh, Amman-Jordan: Jordan University Publications, Deanship of Scientific Research.

- Al-Mutawa, Mahra Hilal, and Maitah, Ibrahim Abedarboh (2005). Educational Supervision, Reality and Ambition, The Third Educational Conference on Educational Supervision, Management of Education Quality, Khalifa Bin Zayed Award for teacher 15 - 16 /4/2005.

- Al-Momani, Ziyad (2003): The necessary administrative competencies for supervisors of youth centers and the degree of their practice from the supervisors' own perspective, Yarmouk Research, Human 
and Social Sciences Series, 19 (2B), 1051-1073.

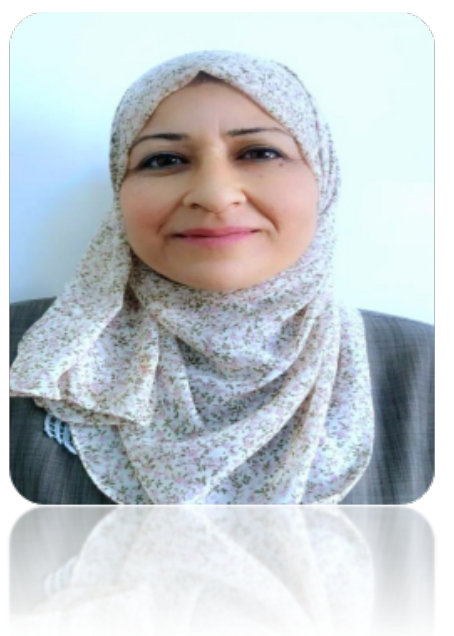

MS. NEJOD ABDALLAH

JORDAN - AL-KARAK

Email ID: nejoodmass@gmail.com
IYADEH

AL MASSARWAH 